\title{
A new population of Darwin's fox (Lycalopex fulvipes) in the Valdivian Coastal Range
}

\author{
Ariel A Farias ${ }^{1,2^{*} \dagger}$, Maximiliano A Sepúlveda ${ }^{1,3 \dagger}{ }^{4}$ Eduardo A Silva-Rodríguez ${ }^{4 \dagger}$, Antonieta Eguren ${ }^{5,6}$, Danilo González ${ }^{8}$, \\ Natalia I Jordán ${ }^{1}$, Erwin Ovando ${ }^{8}$, Paulina Stowhas ${ }^{7}$ and Gabriella L Svensson ${ }^{1}$
}

\section{Findings}

Darwin's fox (Lycalopex fulvipes Martin, 1837) is an endemic of the temperate forests of the Coastal Range of southern Chile, that was reported by Charles Darwin in 1834 in southern Chiloé Island $\left(42^{\circ} \mathrm{S}, 74^{\circ} \mathrm{W}\right.$; Martin 1837). Initially known exclusively from that island, it was considered both an insular subspecies of the chilla fox (Lycalopex griseus Gray, 1837) (Housse 1953; CluttonBrock et al. 1976) and a valid species (Martin 1837; Gay 1947; Osgood 1943). In 1990, a mainland population was reported at Nahuelbuta National Park (ca. $450 \mathrm{~km}$ north of Chiloé Island, $37^{\circ} 47^{\prime} \mathrm{S}, 72^{\circ} 59^{\prime} \mathrm{W}$; Figure 1a) in sympatry with the chilla and culpeo foxes (Lycalopex culpaeus Molina, 1782) (Jaksic et al. 1990; Medel et al. 1990; Jiménez et al. 1991). This supported its status as a valid species, later confirmed through genetic studies (Yahnke et al. 1996). Though this canid uses diverse habitat types, it is highly associated with native forest (Medel et al. 1990; Jiménez et al. 1991; Jiménez 2007). The current population size is not precisely known, but it has been estimated to be fewer than 600 individuals, $90 \%$ of them on Chiloé Island (Jiménez and McMahon 2004; Jiménez et al. 2008). In light of its small population size and the vulnerability of remaining populations, Darwin's fox was classified as Critically Endangered (CR: C2a (ii); cf. IUCN 2012). The discontinuous distribution of Darwin's fox, however, raised questions regarding the existence of other populations in under-explored intermediate areas (e.g., Vilá et al. 2004; Jiménez et al. 2008). Recently, Vilá et al. (2004) genetically identified a Darwin's fox skin from Punta Chanchán $\left(39^{\circ} 21^{\prime} \mathrm{S}, 73^{\circ} 14^{\prime} \mathrm{W}\right)$ and reported possible sightings by local people there and at Fundo Chaihuín $\left(40^{\circ} 01^{\prime} \mathrm{S}, 73^{\circ} 25^{\prime} \mathrm{W}\right)$, but failed to find evidence of living

\footnotetext{
* Correspondence: afarias@bio.puc.cl

${ }^{\dagger}$ Equal contributors

${ }^{1}$ Departamento de Ecología, Facultad de Ciencias Biológicas, Pontificia Universidad Católica de Chile, P.O. Box 114-D, Santiago 6513677, Chile ${ }^{2}$ Centro de Investigación e Innovación para el Cambio Climático (CIICC), Universidad Santo Tomás, Santiago 8370003, Chile

Full list of author information is available at the end of the article
}

individuals. An additional dead individual was reported from the nearby locality of Lastarria (Gorbea district, $39^{\circ} 11^{\prime} \mathrm{S}, 72^{\circ} 6^{\prime} \mathrm{W}$; D'Elía et al. 2013). These localities are halfway between the previously known populations (Figure 1a), suggesting that indeed the range is less discontinuous than was previously suspected.

Here we report camera-trap (Bushnell Trophy Cam, Bushnell Corporation, Overland Park, KS, USA) records of Darwin's foxes in three different protected areas in Los Ríos region, which indeed confirm the existence of an intermediate population (Figure 1b,c). These records were obtained as part of two independent studies and a monitoring program. One of the studies and the monitoring program were conducted in the Valdivian Coastal Reserve (VCR; 40 02' S, 73 $35^{\prime}$ W; 50,250 ha; Figure 1b) during February to May 2012 and throughout 2012, respectively. The third study surveyed two protected areas (Figure 1b): Oncol Park (ONC; 39 42' S, $73^{\circ}$ 18' W; 753 ha; March to May 2012) and Alerce Costero National Park (ACP; $39^{\circ} 59^{\prime} \mathrm{S}, 73^{\circ} 28^{\prime} \mathrm{W}$; 24,694 ha; December 2012 to March 2013).

We recorded Darwin's fox in nine different camera traps (i.e., one or more photos per camera trap), three in each protected area (Figure 1c,d,e). Records from ONC came from transects within the park or close to its border, whereas records from ACP came from the highest elevation within the park. In all these cases, photos were obtained in areas of either old-growth forest or dense understory, with cameras that were baited with raw chicken and commercial lures (Minnesota Brand Bobcat Urine, Caven's Violator-7 and Terminator lures; Minnesota Trapline Products Inc., Pennock, MN, USA). All records from the VCR came from cameras set in an area located close to ACP, including native forests and eucalyptus plantations with dense understory (Figure 1b). We did not use lures in the VCR.

Our records add to the skin reported from Punta Chanchán (Vilá et al. 2004) and the parallel report of a dead individual at the nearby locality of Lastarria (D'Elía 


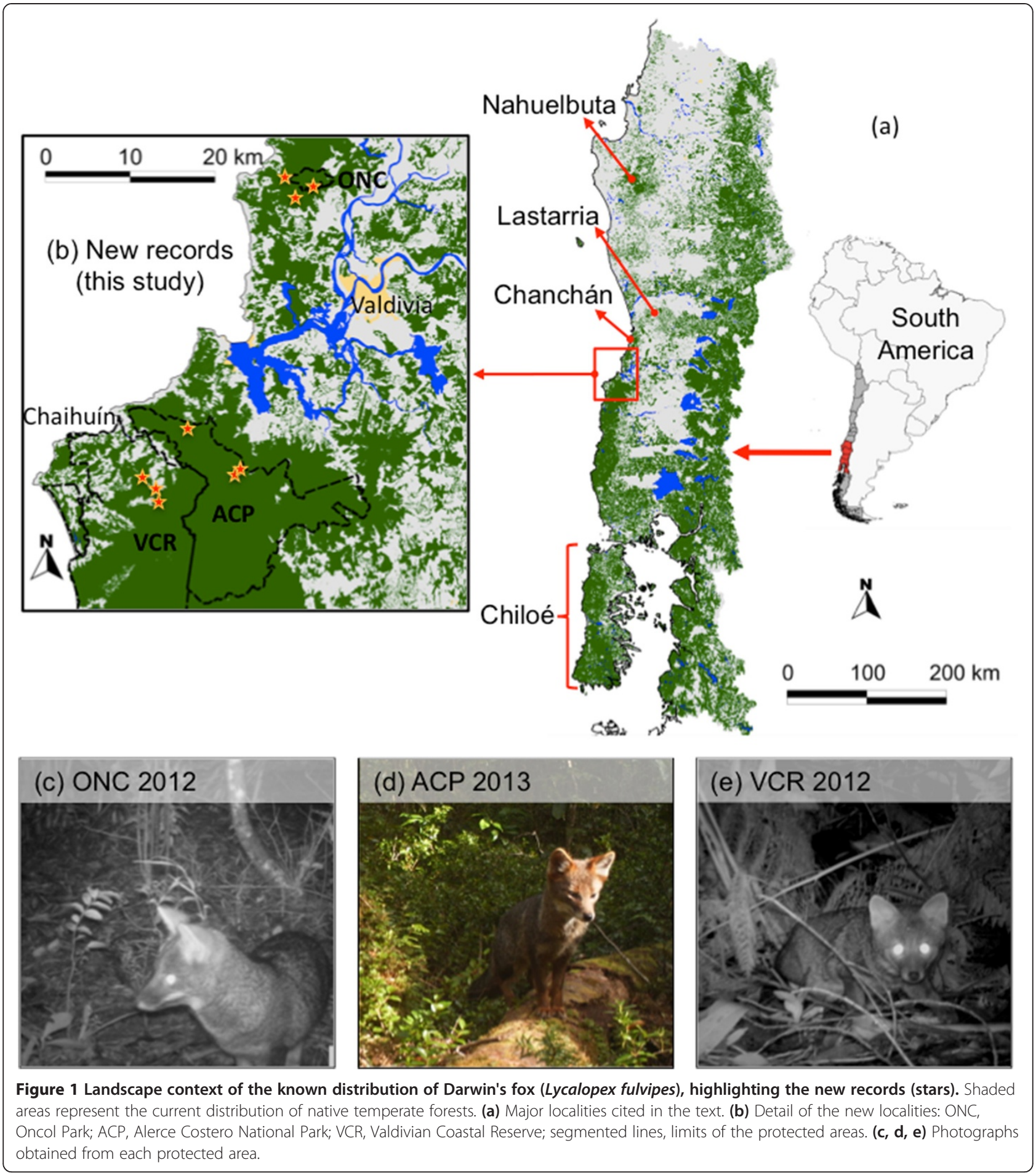

et al. 2013), confirming the current presence of Darwin's fox in the area and suggesting a wide distribution of Darwin's fox throughout the Coastal Range (Yahnke et al. 1996; Vilá et al. 2004). Furthermore, the records from Alerce Costero National Park and Valdivian Coastal Reserve are in the northern extreme of a forested corridor that extends southwards almost continuously for ca. $150 \mathrm{~km}$, covering an area slightly smaller than that occupied by similar forests in Chiloé Island (Figure 1a) where the main population is located. This opens the possibility that the distribution and population size of this canid could be significantly larger than previously estimated. Confirmation of a widespread distribution and population larger than the previous estimate of ca. 600 
individuals for Darwin's fox could require a reassessment of the conservation status (Jiménez and McMahon 2004; IUCN 2012). Further, the current presence of Darwin's fox in the Valdivian Coastal Range, and at the locality of Lastarria (D'Elía et al. 2013), is crucial given that a significant part of this area is currently under protection by the Valdivian Coastal Reserve, the Alerce Costero National Park, Oncol Park and other smaller private initiatives. Nevertheless, the area is not free of anthropogenic threats, such as the projected extension of the coastal highway (Wilson et al. 2005), conflicts between wild carnivores and local communities (Stowhas 2012), free-ranging dogs (Canis familiaris Linnaeus, 1758) (Silva-Rodríguez and Sieving 2012; Sepúlveda et al. (2014a)), and the risk of canine distemper virus (Sepúlveda et al. (2014b)). In consequence, it is necessary to conduct further studies to clarify the actual conservation status of the newly discovered population of Darwin's fox.

\section{Competing interest}

The authors declared that they have no competing interest.

\section{Authors' contribution}

AAF conceived the study at ONC and ACP, and participated in fieldwork; AAF and GLS coordinated surveys at ONC and ACP. MAS and EAS conceived the studies at VCR; DG, EO, AE and PS set and operated the cameras at VCR; MAS, EAS, DG, EO, AE and PS identified the records. NIJ and GLS set and operated the cameras and identified the records at ONC and CAP. AAF, MAS and EAS wrote the manuscript. All authors read and approved the final manuscript.

\section{Acknowledgements}

Grant FONDECYT-11110027 to AAF funded the research at PONC and PNAC, and the Wildlife Without Borders Program (U.S. Fish \& Wildlife Service) and Panthera Foundation funded the work at VCR. CONAF and Forestal Valdivia provided logistic support and access permits. The Nature Conservancy (L. Pezoa, A. Almonacid) provided logistic support at RCV. Park rangers O. Ponce and G. Ponce (VCR) and R. Cárdenas (ACP), along with S. Castillo, N. Glade, G. Carrasco, T. Saratscheff, F. Fuentes, P. Zucolillo, M. Duclos, F. Alfaro, A. Sepúlveda, and A. Silva, assisted in the fieldwork. J. Jiménez, A. Iriarte, and D. Moreira kindly agreed to peer-review our pictures. We thank M. Soto-Gamboa who provided valuable support to our work. We thank the comments by $P$. Feinsinger and $A$. Sigerson that helped improve the manuscript.

\section{Author details \\ 'Departamento de Ecología, Facultad de Ciencias Biológicas, Pontificia Universidad Católica de Chile, P.O. Box 114-D, Santiago 6513677, Chile. ${ }^{2}$ Centro de Investigación e Innovación para el Cambio Climático (CIICC), Universidad Santo Tomás, Santiago 8370003, Chile. ${ }^{3}$ College of Veterinary Medicine, University of Minnesota, St. Paul, MN 55108, USA. ${ }^{4}$ Departamento de Ecología y Biodiversidad, Facultad de Ecología y Recursos Naturales, Universidad Andrés Bello, Santiago 8370251, Chile. ${ }^{5}$ Center for African Studies, University of Florida, Gainesville, FL 32611, USA. ${ }^{6}$ Center for Latin American Studies, University of Florida, Gainesville, FL 32611, USA. ${ }^{7}$ Parcela 50, Quitacalzón, Valdivia 5090000, Chile. ${ }^{8}$ Reserva Costera Valdiviana, The Nature Conservancy, Valdivia 5110489, Chile.}

Received: 4 October 2013 Accepted: 22 November 2013

Published: 26 March 2014

\section{References}

Clutton-Brock J, Corbet GB, Hills M (1976) A review of the family Canidae with a classification by numerical methods. Bull British Museum (Nat History). Zool 29:117-199
D'elía G, Ortloff A, Sánchez P, Guiñez B, Varas V (2013) A new geographic record of the endangered Darwin's fox Lycalopex fulvipes (Carnivora: Canidae): filling the distributional gap. Rev Chil Hist Nat 86:485-488

Gay C (1947) Historia Física y Política de Chile: Según Documentos Adquiridos en Esta República Durante Doce Años de Residencia en Ella y Publicada Bajo los Auspicios del Supremo Gobierno. Zoología. El Autor, Santiago, Chile

Housse R (1953) Animales Salvajes de Chile en su Clasificación Moderna: su Vida y sus Costumbres. Ediciones de la Universidad de, Chile, Santiago

IUCN (2012) IUCN red list categories and criteria, version 3.1, 2nd edn. IUCN, Gland

Jaksic FM, Jiménez JE, Medel RG, Marquet PA (1990) Habitat and diet of Darwin's fox (Pseudalopex fulvipes) on the Chilean mainland. J Mammal 71:246-248

Jiménez JE (2007) Ecology of a coastal population of the critically endangered Darwin's fox (Pseudalopex fulvipes) on Chiloé Island, southern Chile. J Zool 271:63-77

Jiménez JE, Mcmahon E (2004) Darwin's fox, Pseudalopex fulvipes. In: Sillero-Zubiri C, Hoffman M, Macdonald DW (eds) Canids: foxes, wolves, jackals and dogs. Status survey and conservation action plan. IUCN, Gland, pp 50-55

Jiménez JE, Marquet PA, Medel RG, Jaksic FM (1991) Comparative ecology of Darwin's fox (Pseudalopex fulvipes) in mainland and island settings of southern Chile. Rev Chil Hist Nat 63:177-186

Jiménez JE, Lucherini M, Novaro AJ (2008) Pseudalopex fulvipes. In: IUCN 2013. IUCN red list of threatened species. Version 2013.1. http://www.iucnredlist. org/details/41586/0. Accessed 24 Sept 2013

Martin W (1837) Observations upon a new fox from Mr. Darwin's collection (Vulpes fulvipes). Proc Zool Soc London 5:11-12

Medel RG, Jiménez JE, Yáñez JL, Armesto JJ, Jaksic FM (1990) Discovery of a continental population of the rare Darwin's fox, Dusicyon fulvipes (Martin 1837) in Chile. Biol Conserv 51:71-77

Osgood WH (1943) The mammals of Chile. Field Museum Nat History Zool Series $30: 1-268$

Sepúlveda MA, Singer RS, Silva-Rodríguez E, Stowhas P, Pelican K (2014a) Domestic dogs in rural communities around protected areas: conservation problem or conflict solution? PLoS ONE 9(1):e86152, doi:10.1371/journal. pone.0086152

Sepúlveda MA, Singer RS, Silva-Rodríguez E, Eguren A, Stowhas P, Pelican K (2014b) Invasive American mink: linking pathogen risk between domestic and endangered carnivores. EcoHealth, doi:10.1007/s10393-014-0917-z

Silva-Rodríguez EA, Sieving KE (2012) Domestic dogs shape the landscape-scale distribution of a threatened forest ungulate. Biol Conserv 150:103-110

Stowhas P (2012) Conflicto Entre Carnívoros Silvestres y Campesinos en el sur de Chile, DVM thesis. Universidad Mayor, Santiago, Chile

Vilá C, Leonard JA, Iriarte A, O'brien SJ, Johnson WE, Wayne RK (2004) Detecting the vanishing populations of the highly endangered Darwin's fox, Pseudalopex fulvipes. Anim Conserv 7:147-153

Wilson K, Newton A, Echeverria C, Weston C, Burgman M (2005) A vulnerability analysis of the temperate forests of south central Chile. Biol Conserv 122:9-21

Yahnke CJ, Johnson WE, Geffen E, Smith D, Hertel F, Roy MS, Bonacic CF, Fuller TK, Van Valkenburgh B, Wayne RK (1996) Darwin's fox: a distinct endangered species in a vanishing habitat. Conserv Biol 10:366-375

doi:10.1186/0717-6317-87-3

Cite this article as: Farias et al: A new population of Darwin's fox (Lycalopex fulvipes) in the Valdivian Coastal Range. Revista Chilena de Historia Natural 2014 87:3.

\section{Submit your manuscript to a SpringerOpen ${ }^{\circ}$ journal and benefit from:}

- Convenient online submission

- Rigorous peer review

- Immediate publication on acceptance

- Open access: articles freely available online

- High visibility within the field

- Retaining the copyright to your article

Submit your next manuscript at $>$ springeropen.com 